den Klappenersatz im rechten Herzen unbrauchbar. Im linken Herzen sind die Spätergebnisse nach Aortenklappenersatz wesentlich günstiger als nach Mitralklappenersatz. Mitralklappen sind nach Häufigkeit und Schweregrad stärker von Insuffizienzsymptomen betroffen als Aortenprothesen. Die Ursachen für diese unterschiedliche Verhaltensweise könnten mechanischer Natur sein (Klappenmodell, unterschiedliche Hämodynamik, Klappenöffnungsdruck) oder in den Gewebeeigenschaften lebender Fascie (Elastizitätsarmut, Orientierung der kollagenen Fasern bei unterschiedlichem Stress) begründet liegen. Diesen Problemen könnte z.T. in der Verwendung freier Fascientransplantate mit natürlichem Klappenbauplan begegnet werden (wie am NHH bei 62 Klappen erfolgt). Gewebsreaktionen sind evtl. durch die Benutzung nichtlebender Fascie vermeidbar.

\title{
223. Die Chirurgie benigner Vorhoftumoren
}

\section{H. DiтTRICH-Erlangen}

\section{The Surgery of Benign Atrial Tumours}

Summary. Tumours of the heart are extremely rare. Their incidence according to autopsy statistics is on average $0.1 \%$. Half of them are myxomas. At Erlangen, we operated on three atrial myxomas. The tumour can usually easily be enucleated by luxation. Remnants of the easily-damaged tumour can remain in the heart and according to the literature this can lead to a high percentage of fatal embolisms.

The morphological characteristics of such tumours indicate a subendocardial extracapsular resection. This surgical procedure is described in detail.

Zusammenfassung. Herztumoren sind außerordentlich selten. Thre Häufigkeit beträgt in Sektionsstatistiken durchschnittlich $0,1 \%$. Die Hälfte davon sind Myxome. Wir konnten in Erlangen 3 Vorhofmyxome operieren. Der Tumor läßt sich in der Regel leicht durch Luxation enucleiren. Dabei bleiben oft Reste des leicht verletzlichen Tumors im Herzen, die nach der Literatur in einem hohen Prozentsatz zu tödlichen Embolien führen können. Die morphologische Eigenart des Tumors läßt eine subendocardiale extracapsuläre Resektion zu. Über dieses operative Verfahren wird im einzelnen berichtet.

\section{Das Schicksal von über 300 Patienten mit Herzschußverletzungen des 2. Weltkrieges}

\author{
R. NEY-Ulm
}

\section{The Fate of over 300 Patients with Bullet Wounds in the Heart Sustained in the Second World War}

Summary. When among 37 patients with bullet wounds in the heart from the last war, who were admitted to the Surgical University Clinic, Düsseldorf, 29 splinters were removed by surgery, we were dealing with a selected clinical material which was not representative of this disabled group as a whole. 